\title{
THE ROLE OF GREAT MEN AS THE PILLARS OF SLOVENIAN NATIONALISM
}

\section{BOŽIDAR JEZERNIK}

Author discusses the role and meaning of the great men in Slovenian national awakening period within multinational Austrian Empire.

Keywords: Austrian Empire, Central and Eastern Europe, nationalism, great men, Janez Bleiweis, France Prešeren, Valentin Vodnik
Avtor obravnava vlogo in pomen tako imenovanih velmož v slovenskem narodnem prebujanju, ki je potekalo v okviru večnarodnega Avstrijskega cesarstva.

Ključne besede: Avstrijsko cesarstvo, srednja in vzhodna Evropa, nacionalizem, veliki možje, Janez Bleiweis, France Prešeren, Valentin Vodnik

In the Spring of Nations, as Anton Alexander von Auersperg said, "the old links were broken and the bundle destroyed; the ancient might of Austria was shattered and still continues to diminish" (quoted in Apih 1888: 100). The Austrian emperor was forced to adopt a constitution abolishing feudalism, as well as granting the nations of the Austrian Empire the right to use their own languages in schools and administration. This caused great joy among the circles of Slovenian nation-builders, prompting Janez Bleiweis to allude, in his address to the great assembly of the Slovenian Society that he was heading, to the verses of Valentin Vodnik's "Illyria Reborn":

"Let there be light for all the Austrian nations!"- said his grace Emperor Ferdinand on March 15th this year-and there was light! - a sun of new happiness, the sun of freedom shone over those nations. Only now have the words of Vodnik, God rest his soul, acquired their true meaning - it was not Napoleon but our Ferdinand that deserves that famous verse thus paraphrased:

Ferdinand says:

Illyria arise!

She arises and sighs,

Who calls me alert?

Ferdinand calls you, Illyria, our graceful Emperor! (Anon. 1848: 165)

The collapse of the old regime brought about currents of intensive modernization, democratization, and also nationalism. Civil democracy can only function when the majority of people regard the political community as a common undertaking, for which a strong concept of common identity is prerequisite. In the existing reality of that age, revolutionary 
ideas had to carve out their own space by acquiring sufficient numbers of proponents, friends, supporters, and believers. This took time, coordinated work by key actors, and charisma and persuasive conviction from the awakeners of the nation. "Nothing shall happen by and of itself," stated Bleiweis's newspaper Kmetijske in rokodelske novice (Agricultural and Craftsmen's News), "for God is high above us, and the emperor is far away" (Anon. 1861: 85).

The rise and development of national movements in the Austrian Empire followed a certain course, starting with the formation of an ideological core based on Herder's concept of the language as the spirit of the nation. Ethnic groups were then mobilized through the growing education system, the media, social life, and gradual social change. Finally, the constitution formally confirmed the principles of national and linguistic equality (Okey 2001: 285). Within the framework of the Austrian Empire, naturally, the Slovenian nationalists were unable to entertain realistic ideas of establishing a sovereign Slovenian state, which is why they channeled those ambitions into a reinforcement of a new, nationalistically centered interpretation of the past, assuming monopoly over its control (cf. Ferro 1984: viii). Their declared goal was the struggle for "national equality" similar to the aims of related Ukrainian, Lusatian Soerbian, and Slovak organizations, and their activities were therefore masked by the apolitical guise of focusing on the development of the nation's language and its rights in public life (see, e.g., Jezernik 2014: 18).

\section{THE HABSBURG EMPIRE AND THE EMERGENCE OF NATIONALISM}

The awakening of the Slovenian nation within the multiethnic Dual Monarchy was an arduous project. As the nation-builders attempted to mold the Slavic people into the (Slovenian) nation, they had to be wary not to arouse the suspicion of disloyalty to the ruling dynasty. This is why they frequently presented the Slovenian nation as an entity intrinsically loyal to the emperor, a faithful community grateful to the magnate as the father figure of its constitutionally recognized national equality. When the fifth Slovenian reading society was ceremoniously opened in Tolmin in 1862, the speech by its president, the noble Janez Premerstein, celebrated "our illustrious emperor, who with his decrees from October 10th, 1860 and February 26th, 1861 elevated our Slovenian nation to a state of civility and prosperity, having declared its language equal to those of the empire's other nations":

Yes! Indeed, the Slovenians hearken once more to the words of Vodnik, now uttered by our great and mighty emperor, who calls: Slovenia, ascend!-And it has ascended. (Luznik 1862: 77)

The first Slovenian nationalists had neither the leverage nor the resources to implement their interpretation of the past as official history. It was merely one of the possible interpretations, a relatively obscure one in the empire of the time, pressed to jostle for position against 
the heavy competition of the official records of history supported by a powerful military and a ubiquitous bureaucratic and law-enforcement apparatus (Jezernik 2014: 151). During the years of Bach's absolutism in particular, the nationalists' policies were running quietly, in tiny steps, far removed from the spotlight. On the other hand, it should be noted that loyalty to the Habsburg dynasty was in no way incompatible with Slovenian identity at the time. Up until 1918, in fact, Slovenian identity was seen as inseparably involved with Austro-Slavism, and it was not until its redefinition after the establishment of the nationstate of the South Slavs, following the First World War, that the historical Slovenian stance was portrayed as anti-Habsburg in nature, an image that was then retroactively applied to the times preceding 1918 as well.

By securing a good impression of its aims and activities in the eyes of the imperial authorities, the Slovenian political elite accomplished only a secondary task of its struggle. The primary one, in many regards even more difficult to effect, was gaining the trust of the people so that they would follow and support its various efforts. If it could not attract the spirit and hearts of men to its cause, its ideas would never become a material force. This is why the movement of the awakeners of the nation had to "comprehend, first and foremost, the spirit of the age and the current development and mentality of the people" (Sernec 1927: 107). Observation of the masses' way of thinking instructed them that six centuries of shared history bound the people to the imperial figure in a way so that "the emperor is now the name of their father, the name of their defender, a magnificent name cherished as the highest worldly authority" (Lampe 1894: 514). The Slovenians of the time already acquired such a disposition in their homes, and it was further reinforced by the education system as well as the Catholic Church, which backed the emperor as the protector of the holy faith (Lampe 1894: 514). Thus, in order for nationalist propaganda to be successful, it had to be positioned as a phenomenon compatible with the emperor's approval and the nation's loyalty to the dynasty.

The process of the Slovenian national awakening within the Austro-Hungarian Empire presented the Slovenian political elites with considerable limitations regarding available instruments as well as their utilization. Proponents had to be careful not to provoke the anger of the central authorities, avoiding the impression of a political movement, let alone political opposition. Had they incurred the wrath of the imperial government, it would have likely suppressed Slovenian nationalism in its earliest stages, branding it as an antiAustrian and anti-dynastic movement and punishing its protagonists as traitors or agents of disruptive Pan-Slavism. In such a case, they likely would have also revoked the language rights granted to the schools and offices, sending Slovenian back underground into the pits of "the disfranchised, the dispersed, and the Germanized" (Sernec 1927: 107-108).

Additional barriers were also imposed by the Slovenian nation's own sociopolitical, cultural, and historical circumstances at the time. The European nationalisms of the nineteenth century focused primarily on three elements to be employed by new political communities, or nations, as they forged their confidence: the creation of a great political 
entity, the engagement in the struggle for great ideals, and the actions of great men that represent their culture to the world (dr. I. L. 1919: 2).

Out of these three elements, the Slovenian awakeners of the nation that attempted to build a nation from centuries of subjugation and oppression and a lack of political independence, having neither formed their own state nor fought great wars in its name, had at their disposal only the third of these: the element of great men, especially those that spoke publicly in Slovenian. In this, they leaned on Thomas Carlyle and his theory, according to which "Universal history, the history of what man has accomplished in this world, is at bottom the History of the Great Men" (Carlyle 1841: 1). Because the Slovenians were without their own state, the idea of the nation as put forth by the German romantics, serving as the template for the German nation-state, was highly appealing to them; it "gave the nation a life independent of the state" (Vošnjak 1913: 541). Based on such an understanding, they thus summoned the image of the Slovenian nation, one arising separately from the state, and whose existence demanded merely its own culture, and especially the preservation of its own language. The literary historian Julij Kleinmayr even asserted that the history of the Slovenian language was in fact synonymous with the history of the Slovenian nation as such because language was "the sole bond holding us intrinsically together," and therefore "the singular, greatest treasure of all the nation's sons" (Kleinmayr 1881: 3).

Under the given circumstances, Slovenian was thus attributed the role of the nation's foundation stone. "A nation without national awareness is a body without bones," wrote Janez Bleiweis, "and the soul of national awareness lies in the nation's language" (Anon. 1862: 322). Nation-builders considered the native language to be not only the firmest of bonds between the people, but also their essential belonging. Care for fostering the language and its preservation was put forth as the most vital characteristic of "kindred love" (Ilešič 1908: xviii). In addition to its vocal content, stressing the significance of Slovenian also carried silent meaning: in the process of struggling for the visibility of Slovenian, the fledgling Slovenian nationalism was able to don an apolitical cloak, although it was fundamentally a political movement (see Jezernik 2007: 145). This mimicry was the guiding principle of the slavno slavljenje slave slavnih Slovanov ("the festive celebration of the glory of famous Slavs"). Every memory, namely, is socially constructed within specific frameworks of concrete reality and shaped according to the interests of the present time, thus constituting the engine as well as the product of political struggle. Celebrating the glory of famous Slavs was meant to prove that Slovenians did not lag behind other nations, but, because those that were propagating nationalistic ideas could not risk shedding doubt on the loyalty and faith of the Habsburg dynasty's subjects, for this role they predominantly chose men of letters; men of arms were only eligible if their arms performed heroic deeds in service of the emperor (Jezernik 2014: 105-107). 


\section{STARS IN THE SKY AND NATIONAL POLITICS}

The rise of nationalist movements brought with it a change to the methods and forms of political struggle, placing particular focus on mass identification with the icons of the new national identity. In their understanding that the cause would not advance without the instilment of national pride, the nationalists fueled their countrymen's confidence by celebrating great men of common ancestry that had achieved noble tasks for the benefit of the community in the past (see, e.g., Glaser 1894: iv). Nations thus promoted and aggrandized their chosen great men to the best of their abilities. Regions and cities competed for the honor of naming one of their own a national hero. By cherishing these, they reinforced national consciousness and pride while also legitimizing the corresponding political goals of the elites, in the present and in the future (Jezernik 2014: 76). In light of the prevailing view that a nation has "as many bright stars in the sky to light its way through history" as it has famous men among its ranks, the Slovenian nationalists also tried to persuade the nation to celebrate as many of its men as were eligible for national honors, stating that for each man "immortalized in their nation's memory" a bright star would appear in the Slovenian sky "illuminating the way to a prosperous future" (-nc 1889: 1).

In the nineteenth century, European nations began distinguishing themselves from one another based on certain patterns that were themselves a product of cultural interaction and exchange, and based on public accentuation of their unique individual character and cultural identity (see Rigney \& Leerssen 2014: 5). In this endeavor, they put to good use the life stories of their distinguished personalities, their great men that were presented as "the embodiments of their age, vital sources of enthusiasm and encouragement" (Gangl 1905: 3). The selection of personalities that were to be revered by the population-to be remembered in the attributed context of a "brighter future"-was of strategic importance. Namely, group identities also develop to a significant degree through the reconstruction of the past, its problematizing, and its retouching. Although the proponents of the national awakening never admitted this out loud, they nonetheless always propagated certain political and existential ideologies with their choices of representative personas, and, alongside these, specific social, political, and cultural aspirations. "Memory," suggests James Young, "is never shaped in a vacuum and the motives of memory are never pure" (Young 1993: 2).

Preserving the memory of the appointed great men—and the parallel forgetting of others-constructed new levels of interpreting the past and projecting the future. "The future is the daughter of the present and the past," contemplated Lovro Toman. In his views, the creation of a fortunate, glorious future demanded the removal of the "barriers and errors that in past days stunted the national progress" (Toman 1862: 9). The choice of appropriate historical personalities whose memory was to be made exemplary and preserved thus always contained an ideological charge. On March 29th, 1876 the newspaper Novice gospodarske, obrtniške in narodne described this phenomenon in the following manner: 
Nowadays if a party has it in mind to glorify its particular principles, they trump up a story on the name day of some living magnate, or by the tomb of some dead one; they choose for themselves a person to suit their means and ends, and thus proceed to gloriously advertise it to the world, whereas the underlying motive is always, rest assured, the glorification of the party's own agenda. (Anon. 1876: 98-99)

The presentation of the past is always closely connected to political processes, especially the politics of representation; that is, making decisions about who can represent whom, how, where, and on account of what; who controls history, who has the moral right to control it, and in whose interest they are operating these instruments. By singling out certain historical personalities, the key actors not only portrayed specific histories, but also co-created them for public consumption. Historical consciousness shaped in this way gave those that portrayed it a mark of legitimacy because it appeared in the public arena as the objective truth, seemingly disjoined from politics and authority. Because the aim of national memory thus constructed was to serve the struggle for national awareness, the past represented by the great men was wholly a product of present conditions, their ideological and political issues, negotiations, and conflicts (Jezernik 2014: 130). This is why the Slovenian interpretation of the past was constantly changing, from one generation to the next, amending itself as necessary and adapting to the specific requirements of the times, all the way up until the image of national history acquired an antagonistic stance in relation to imperial history and its own reconstructions of the past.

\section{CELEBRATING THE DEEDS OF FAMOUS SLAVS}

The importance of the popularization of great men for the purposes of national awakening was well understood by Janez Bleiweis, the editor of Kmetij/ke in rokodélfke novize, the most influential newspaper published in Slovenian, who announced on the front page of the very first edition that "any true Carniolan wishes to know about his Carniolan land, to be acquainted with its great men, and to follow their past and present undertakings," stating furthermore that the fulfilment of this wish shall require "our most diligent effort" (Anon. 1843a: 1). In 1852, editor Bleiweis began systematically publishing the biographies of great Slavic individuals, both in the aforementioned Novice as well as in Koledarčik slovenski. His aim was not only to familiarize the readership with the life and work of noted individuals, but especially to encourage national (self-)awareness:

The simple folks, our Slovenian folks in particular who have never had much to read in their own tongue, have heard little of these matters until now. Lord have mercy—it wasn't so long ago that many Carniolans still did not know that 
the Styrians, Carinthians, and also those inhabitants of the Gorizia region, the Littoral, Hungary, and Venetia who shared their ancestry and their speech were all part of the Slovenian nation, together!- - being furthermore unaware that Slovenians themselves were part of the greater Slavic brotherhood. Even our gentry, alas, was ignorant of these matters but some few years ago- - how could one, then, fault our everyman?

Now-as I hope and believe-when even our everyman and certainly the wise readership of this publication knows what a Slovenian man looks like, and that we Slovenians are furthermore all sons of the great Slavic people, and thus the fame of the Slavs likewise belongs to the Slovenians-now-I daresay-is the time we should be telling the stories of our nation's great men, those gems of the Slavic people- (so that our elders can be proud of the nation they have spent their lives being part of - and our young shall have a worthy example, a great example and a source of pride, to follow and act for the honor and glory of their nation and their own selves. (Anon. 1852: 138)

As Andrei Markovits asserts, nationalism in Central and Eastern Europe represented a social force wherein people emphasized similarities with "brethren" beyond the immediate horizon while at the same time discerning previously ignored differences between themselves and their "foreign" neighbors. This was a political manifestation of hitherto poorly accentuated cultural, linguistic, and social bonds. The common tradition-or conscience collective - was extended geographically, politically, and socially, while similarities as well as differences were increased in terms of speech, dress, and habits (Markovits 1982: 9).

Employing emotional rhetoric, suggestive symbolism, and dramatic rituals, the nationalists encouraged people to internalize the overarching importance of nationality. In this way, for example, Franc Malavašič wrote enthusiastically in Novice in 1861 that nationality had become the essential motto of every nation's colors. In his words, the national spirit was "a pearl cherished and protected by each nation under the sun as the crown of its essence, the anchor that fastens firmly the ship of the people to its safe haven when it is being threatened by raging currents, treacherous waters, and the peril of sinking." As this idea "burst from within all the nations at once, like a miraculous spark," Malavašič continues, it results in "a vibrant flame fueling the pen of each and every patriot" (M. 1861: 279).

The more a nation is in tune with its national core, the more it feels within itself the resolute strength to realize its calling, and its spirited and resourceful individuals then act as God-chosen conduits and teachers in our difficult and perilous struggle of life, to rise as bright stars in the clarion skies of history. In this sentiment, the nations are not only aware of themselves; brother comes closer to brother, offering a firm handshake in a sign of kindred spirit, a token of friendship in hardship and joy. As our immortal poet uttered so proudly: "Most of this 
world belongs to Slavdom's races," so do we with joyous and resolute hearts add that these very races, the children of one great Slav mother, respect one another more dearly, love and support one another more firmly from each day unto the following one. We Slovenians have until recently slept a dreamless slumber; just how were we supposed to be watchful and foster our strength when we had been surrounded by a thousand-year-long darkness? Darkness is never the ally of progress. Now, though, even to us the waking call rings, and we rise, though our sun has not yet ascended the joyous skies, we yet see the kindling dawn heralding its coming. (M. 1861: 279)

All of the European nationalists stressed the uniqueness and preciousness of their own nations, and presented national sentiment and heritage as the expressions of an endogenous national spirit. Nevertheless, they all employed similar instruments in their patriotic speeches when addressing their brethren, with only the "names of historical persons and events being changed," as ascertained by Ljudmil Hauptmann, "all other activities are always and everywhere the same: grandiose words, passionate and fervent, enthusiastic and encouraging, describing the fame, heroism, greatness, and peerless natural righteousness of one's own nation" (Hauptmann 1938: 427). In spite of their individual exclusivist pretense, the burgeoning nationalisms of the age were an international phenomenon. In this context, national consciousness did not and does not exhaust itself in the bare sentiment of belonging, but always mobilizes the population for the realization of the (political) goals of the national community (Jezernik 2013: 27).

The past involves the activity of countless individuals. The actors of the national awakening singled out only those that legitimized their efforts and could be presented as embodiments of their particular values. In this sense, the national awakening intrinsically carried with it a politicization of culture, the mobilization of cultural forms for ideological purposes. Thus, it was stressed that familiarity with the great men and the celebration of their work and merits for the nation "was as important a duty as following their famous examples" (Kleinmayr 1881: 9).

The individuals that were admitted the great man status by the community were transmuted into the image of the nation. The cult of the nation's great men served to reinforce communal solidarity and build a sense of one's "own worth" in contrasting relationships with representatives of other nations. All of this contributed to the cultural homogenization of a particular nation's population and the delineation of borders between Us and Them. In nationally mixed spaces, the so-called national awakening sooner or later evolved into conflicts between these nations, because — as Dragotin Lončar put it— "Each nation arrived at the table with its own demands, many incompatible or conflicting with those of the others" (Lončar 1909: 150). Everywhere, the nationalists strove to "instill in the malleable hearts of our youth already at an early age the sentiment of national consciousness and pride, so that it shall not waver as they grow, and so they do not stray from the path 
of their kin." Because each nation demanded for itself an exclusive right to a specific territory, conflict between them became an increasingly serious matter. Slovenian nationalists often expounded that they were waging "a desperate life-and-death struggle in the north, the south, and the west" (Anon. 1905: 1).

\section{THE "FIRST SLOVENIAN POET"}

The pressures of modernization and democratization across the Austrian Empire pushed the Catholic clergy into an unexpected role. Having been active throughout the empire's territory for centuries, even in the remotest of its villages, the church was in fact the single organization whose influence extended over all the nooks and crannies of the land. It could be that the role of the clergy was most profound precisely in regions that had a Slovenian population because civil society there was relatively poorly developed and a Slovenian aristocracy did not exist. Accordingly, Slovenians were "in essence a church-organized nation" (Prepeluh 1938: 64; cf. Sperber 2001: 718). This meant only such ideas that could pass the evaluation and motives of the clergy could be proliferated effectively. Ivan Tavčar, in his "account of the times for future comprehension," painted what is now Slovenia simply as "Papal province no. LII," where authority belongs to the Ljubljana Archbishop (Tavčar 1891: 131), whereas men of letters write "prayer books and little else" (Tavčar 1891: 68).

Members of the Slovenian clergy were themselves mostly recruited from the ranks of the peasantry, intimately attached to the land of their ancestors. Slovenian nationalism, which in the mid-nineteenth century became the driving force of local modernization, thus on the other hand assumed a markedly conservative rhetoric and orientation (Jezernik 2014: 140-141). This was also the leading reasoning behind the choice of Valentin Vodnik (1758-1819) as the first icon of the Slovenian nationalists because he was the one that had handed the Slovenian nation "the key to the vault of language, kindling the light of folk poetry" (Toman 1858: 30). Vodnik was a solid choice, internally as well as symbolically. On the outside he was agreeable to representatives of both the peoples of Carniola, having already been immortalized in the building of the Provincial Museum of Carniola (the "Rudolfinum") as one of the four famous Carniolans alongside the polymath Johann Weikhard von Valvasor, the mineralogist and patron of the arts Sigmund Zois, and the statesman Sigismund von Herberstein (Anon. 1889a: 445). The act of raising Vodnik to a national pedestal was thus not related as much to his poetic prowess as it was to the political character of the times (Jezernik 2007: 172).

Reporting about the Vodnik Days celebrations held by reading societies across the land, Novice gospodarske, obrtniske in narodne frequently used enthusiastic language. These activities, dubbed vodnikovanje, reinforced the cult of the "first Slovenian poet" with recitals of Vodnik's poetry or texts and songs composed in his memory. Thus, the cult of Vodnik "contributed much to the spreading of Slovenian national thought" (Gspan 1958: 
148-149). The journalist describing the national celebration of Vodnik's memory conducted on Candlemas 1869 wrote that the event amply displayed that Vodnik's call "Illyria, arise!" was not one uttered by a solitary soul. "Whoever was present at that celebration," reported Novice "could firsthand observe that the national idea is no empty fancy, as some wish to suggest, but flesh and blood in action - a flame that shall not be extinguished by any gale, even one as strong as to tear the oaks from the ground, because it is perpetually invigorated by our national consciousness" (Anon. 1869: 48).

The central authorities of the Habsburg Empire did not see any potential threat in commemoration of that "masquerading monk," who, according to France Prešeren, "loved to sing, and loved to drink even more," and the organization of the vodnikovanje events was permitted without much ado. The celebration of the "Slovenians' first poet" also served as a smokescreen concealing the friction among the nationalists themselves (Jezernik 2014: 107). An evolving perception of the external threat compelled the people towards unity, whereas national unity galvanized them in their struggle against foreign danger, in turn dissolving internal national divisions. The symbolic construction of the community and its boundaries was thus oppositional in character: Slovenians were defining themselves mostly in relation to Others, especially the ethnic Germans. In this light, Slovenian identity was primarily specified according to what the Slovenians were not. In his editorial in the newspaper Slovenski Narod, Josip Jurčič stated laconically, "as long as we are not Germans we shall be content (as it is self-evident we have no wish to be Hungarians or Gypsies either). Against Germanization, though, we are prepared to fight to the death" (Jurčič 1876: 1).

The age of national awakening brought great tangible evidence of progress in all areas of social and cultural life, but it did not result in the one thing cherished in the rhetoric of the national awakeners as the holy grail of their movement: national unity. Especially after Slovenski Narod moved its headquarters from Maribor to Ljubljana, the stubborn opposition of "old Novice," published by the conservative Old Slovenian party, against everything that hailed from the Young Slovenian party (the national liberal camp) grew increasingly palpable, from one publication to another. It seemed as though discussion about national harmony in fact fanned the new flames of national discord. In 1873, Novice gospodarske, obrtniške in narodne was already asserting that the rift among Slovenians themselves was growing more evident "each and every day." This is why they proposed establishing two parties, with Novice's and Narod's programs, respectively, "so that birds of a feather may flock together and provide a common, firm voice to their respective parties"; asserting that "politics that wanders now hither, now thither, quarrelsome and indecisive" yields only "a rotten harvest" (Anon. 1873a: 103-104).

The existence of competing groups and power dynamics within every nation inevitably leads to the formation of competing, diverging views on historical personalities and events, something that also occurred on the Slovenian political stage. The fork in the Slovenian political arena took place in the specific circumstances of the struggle for the nation's rights and the use of Slovenian in schools and offices. At the turn of the century, 
the domain of political conflict shifted from a differentiation between the Slovenian and the German-oriented political parties to differentiation within the Slovenian majority itself. The increasingly structured tendencies within the Slovenian nation invariably resulted in the diminishment of initial unity. The result was the formation of the National Liberal Party, dubbed the Young Slovenians, as the political representative of the burgeoning gentry, and the Catholic National Party, dubbed the Old Slovenians, as the political representative of the rural majority. As Anton Mahnič wrote, from there on, the Slovenian community was divided and joined on the basis of religious attitude: on one side were those that "stand defiant against the nation's faith, its millennial tradition and history," and on the other side those that "wish to fight and die under those old familiar banners of God, the homeland, and the emperor" (Mahnič 1889: 563).

Unity forged through opposition to a common external enemy dissipated along with the loss of the enemy's strength, which occurred on Slovenian territory parallel to the reinforcement of national consciousness and interconnection. Nonetheless, the stronger the national consciousness and its activities became, the more apparently discord within the nation itself could be felt. The new dynamics of political life were no longer dictated by resistance to an external enemy, but by the internal division between the parties themselves, whose members began waging heated debate and hostilities against the internal enemy, "even in the remotest of villages." At the outset of the twentieth century, according to the newspaper Slovenec, humanity found itself divided "by an insurmountable abyss." Across from each other stood two cultural monoliths, two worldviews comprising man as a whole and all of his efforts, ruling over science and the arts, education and economics alike, a division between those "following the Lord as their supreme authority and those renouncing His name and His church"; a division more powerful than even the economic interests or the worldly conflicts of entire nations (Anon. 1904: 1). Similar opinions were entertained by the editor of the second Trubarjev zbornik (Trubar Compendium), Fran Ilešič, who in his editorial contemplated the presence of the dead. Commenting that those deceased "who truly dedicated their existence to ideas" were ever-present among the living, he lamented that at the time of Trubar's four-hundredth anniversary conditions within the nation were such "as if the bonfire of the sixteenth century were still lit," with the two stubborn political camps of the Slovenian nation clashing against each other "as if they were enemy nations, as if locked perpetually in the sixteenth century" (Ilešič 1908: viii).

\section{THE “SLOVENIAN COAT-OF-ARMS”}

The Old Slovenian party strove to organize and awaken the Slovenian nation in broad strokes. For reaching the masses, sophisticated aesthetics were not nearly as useful as practical teachings. When it came to poetry, thus, they recognized in the poems of Valentin Vodnik and Janez Vesel (pen name Jovan Koseski) effective tools for nation-building 
purposes, whereas France Prešeren suited their agenda to a far lesser degree. The authors of the first Slovenian secondary-school readers, Janez Bleiweis and Fran Miklošič, who were considered the creators of the political concept of Slovenia, dedicated only meagre space in schoolbooks to the poems of Prešeren (Ilešič 1902: 152-153). Bleiweis, the "father of the Slovenian nation," held particular reservations about the poet because he regarded him, as he explained in his letter to Josip Cimperman, as far too liberal-minded, and, furthermore, not someone that ever actively vied for the public rights of the Slovenian language. Accordingly, he branded him "a poet and nothing more":

Indeed, Prešeren was an excellent poet of ours, one we may rightfully take pride in and exhibit to others as an example of masterful verse-crafting. But let us not make him into more than he was, so that his cultus is not-exaggerated. (Cimperman 1883: 191)

In the years following Prešeren's death, though, the great poet was intermittently brought to public attention by the Young Slovenian party; for example, in 1863, when their newspaper Naprej proposed that now, when "Slovenians have already shown so much gratitude to Vodnik," our "greatest and single true poet Prešeren" deserved to be celebrated in Ljubljana, too (Anon. 1863: 40). Nonetheless, Prešeren remained in Vodnik's shadow for decades, more than likely for political reasons (Jezernik 2014: 158). It was not until the great festivities of Sunday, September 10th, 1905, when Prešeren's statue was unveiled at what was then Ljubljana's largest square, that society finally enthroned him as the "foremost Slovenian poet" in the sense of the public valuation that he has held ever since, announcing him to be the most important icon of the Slovenian nation. The unveiling of Prešeren's monument on St. Mary's Square in Ljubljana was the crown of a process that, as Karel Slanc put it in 1874, "sat the might of literature onto the throne of the world, hitherto occupied by the Church" (J. Sl...c 1874: 2).

This change in the national perception can be credited in great part to Josip Stritar, who in 1866 together with Josip Jurčič compiled a new edition of Prešeren's poems and wrote its aesthetic and critical introduction. Stritar turned the previous evaluation of Prešeren's poetry upside down, praising the poet as a quintessential figure of Slovenian literature, planting the seeds of his cult-like status. He proposed that Prešeren was to Slovenians what Shakespeare was to the English, Racine to the French, Dante to the Italians, Goethe to the Germans, Pushkin to the Russians, and Mickiewicz to the Polish (Stritar 1866: 15-16).

Nevertheless, the celebration of the centenary of Prešeren's birth occurred during a heated election battle (Aškerc 1901: 72). In the context of such a reality, the idea of national unity transcending partisan divisions was just a beautiful dream. It could not be summoned into social life, not even by the poetically inspired encouragement transmitted as the fictional words of the Slovenian nation's genius Prešeren, imagined "standing between the two warring camps, chiding them thus": 
Countrymen! Life is a struggle, and our cultural-political life is a struggle as well. Is it any different with any other nation, though? Personal and political interests struggle ever with true ideals, the higher goals of progress, justice, and humanity. Traitors are those who put their base partisan interests above loftier aspirations, above the cultural prosperity of the nation! Devious are those pursuing dishonest means! ... Brothers! Your holy goals ought to be progress, civility, freedom! As you bicker and quarrel, do not lose these goals from your sight, and do not forget that you are, after all, brothers by blood and together Slovenians in need of one another's assistance in your struggle against common enemies. In necessariis united, you do amount to something, but lacking unity-you are nothing. Do not ever forget, your foes prey on you from all sides to subjugate you even further than you have already been subjugated .... Can you not see that great flood of foreign gall crashing against the crumbling dams of your national unity? (Aškerc 1901: 72-73)

Such calls, though, did not assuage the political tumult, nor convince the "tired factions" to lay down their arms and shake hands as purportedly advised by the spirit of their national poet (Aškerc 1901: 73). Although the Catholic-nationalist circles did admit the "foremost Slovenian poet" France Prešeren's stature, to them he was not nearly as appropriate a national icon as the foremost Slovenian poet in the nationally historical sense, Valentin Vodnik. When the liberal Ljubljana mayor, Ivan Hribar, summoned a constitutional meeting of the Slovenian mayors' association in 1900, the conservative camp immediately issued their statement that the "Catholic-nationalist mayors will not be attending the meeting because they do not wish to participate in a parade of liberalism serving to advertise its propaganda to the Slovenians" (Anon. 1900: 4). In fear that the elevation of the freethinker Prešeren was a veiled attack on Catholic values, and that large-scale presence at a ceremonial unveiling of his monument would appear as a public sign of the modern embrace of secular values, they even assailed the entire Prešeren statue campaign. The newspaper Slovenec accused those that had erected the monument of exploiting Prešeren's name for the purposes of "enticing the people towards their materialistic views through the use of sensual impulses." They claimed Prešeren had always idealized his passions, being as a poet in fact an opponent of unaesthetic and crass materialism, and that the users of his likeness were now dragging his leftover decency through the mud with their associations (Anon. 1905ad: 5). On its pages, the newspaper launched a heavy offensive against "the Valjhuns of the materialistic worldview who know only raw carnal instincts and operate on behalf of the animalist Darwinist agenda." Contemporary Slovenian freethinkers were blamed by Opazovavec ("the Observer") in Slovenec for being worse than pagans, having descended "even lower than the old pagans, in fact, because those were at least searching for their own truth, whereas these only ridicule it" (Opazovavec 1905: 1). 
Great men, thus, do not occur on their own, but are proclaimed as such by historical agents. In every society, there exist several groups competing for social dominance; in each society there are several different collective memories of historical personalities and events, and that is why every society lives with manifold parallel notions about which of the mythical and historical events and characters ought to be remembered, and in what light. These competing memories are not static, but involve a process of constant reshaping of meaningful and non-meaningful content. The reconstruction of stories about the past involves facts woven into them by the narrators, with the intent, be it conscious or subconscious, to reaffirm their expectations and beliefs. In brief, the narrative image of personalities and events from the past is a process of constant (re)evaluation, whereas the stories themselves always express particular ideological, political, ethical, and other conceptions employed by individuals and groups of people in order to interpret and evaluate what is current and what is irrelevant, what is important and what no longer matters.

Radical change in the political system frequently also brings change to the symbolism of a particular society. Old symbols give way to new ones, which represent and reinforce new ideologies and new political powers. These dynamic processes normally highlight individuals that represent, if not outright embody, the desired ideas and values, filling them with powerful emotional content. In this sense, the rise of nationalism in the second half of the nineteenth century brought great changes to the selection of perceived great men to be set as the example to the Slovenian community. In 1860, it was still someone like Field Marshal Radetzky that received a public monument in Ljubljana (whose honorary citizen he had been, having lived there briefly), followed by a second statue, a full twenty years later; however, the fledgling Slovenian national awakening focused on radically different profiles. Both monuments to Radetzky were ultimately demolished by unknown "patriots" in early 1919 (Jezernik 2014: 54-73). The upheaval that occurred with the Great War's passing was survived only by the "national monuments" that had previously served to symbolically mark the space as Slovenian and after the war became defenders of de-facto Slovenian territory. Surviving monuments were only those that supported the interpretation of Slovenian history as a linear and clear-cut story describing the link between the revolutionary present and mythical past, evoking the thousand-year-old struggle between good and evil (Plumb 1969: 98).

According to this narrative, the heroes of today ("we are like them") introduced by political change did not merely replace the old heroes, now yesterday's villains ("we are not like them"), but also pushed that which had previously been periods of historical focus into collective forgetfulness (Jezernik 2014: 396). 


\section{REFERENCES}

Anonymous. 1843a. Osnanilo. Kmetijfke in rokodélfke novize (July 5th): 1.

Anonymous. 1843b. Prôfhnja. Kmetijfke in rokodélfke novize (July 26th): 13.

Anonymous. 1848. Nagovor. Slovenija (November 24th): 165.

Anonymous. 1852. Življenje slavnih Slovanov. Vvod. Novice kmetijskih, obertnijskih in narodskih reči (May $1 \mathrm{st}): 138-139$.

Anonymous. 1861. Slovenci! Novice gospodarske, obertniške in narodne (March 13th): 85.

Anonymous. 1863. Beseda Ljubljanske čitalnice, Vodniku na spomin. Naprej (February 3rd): 40.

Anonymous. 1869. Narodna svečanost Vodniku na spomin. Novice gospodarske, obrtniške in narodne (February 10th): 48-49.

Anonymous.1873a. "Novice" in mestne volitve. Novice gospodarske, obrtniške in narodne (March 26th): $103-104$.

Anonymous. 1873b. V Gorici. Soča (April 3rd): 3.

Anonymous. 1876. Nemčurske demonstracije grofu Antonu Auerspergu. Novice gospodarske, obrtniške in narodne (March 29th): 98-99.

Anonymous. 1889. Das Museum in Laibach. Laibacher Zeitung (March 8th): 445-446.

Anonymous. 1900. Županska zveza. Slovenec (June 2nd): 4.

Anonymous. 1904. Kulturni boji. Slovenec (December 3rd): 1-2.

Anonymous. 1905. Klerikalna gonja proti Prešernu se nadaljuje. Slovenski Narod (September 21st): 1.

Apih, Josip. 1888. Slovenci in 1848. leto. Ljubljana: Matica Slovenska.

Aškerc, Anton. 1901. Praznovanje Prešernovega jubileja; Ljubljanski Zvon 1: 72-77.

Cimperman, Jos. 1883. V spomin dr. Jan. viteza Bleiwewisa-Trsteniškega. Novice gospodarske, obrtniške in národne (June 13th): 191-192.

dr. I. L. 1919. Spomenik stare slovenske slave; Jugoslavija (March 19th): 2.

Gangl, Engelbert. 1905. Slava Prešernu! ob odkritju Prešernovega spomenika v Ljubljani. Ljubljana: Narodna tiskarna.

Glaser, Karol. 1894. Zgodovina slovenskega slovstva. Vol. I: Od početka do francoske revolucije. Ljubljana: Slovenska matica.

Gspan, Alfonz. 1958. Izbrane pesmi Valentina Vodnika. Ljubljana: Slovenska matica.

Hauptmann, Ljudmil. 1938. Svetovna vojna in naš nacionalizem; Ljubljanski Zvon 427-433, 529-535.

Ilešič, Fran. 1902. Opombe o publikacijah “Slovenske Matice” za 1. 1901. Popotnik 5: 145-154.

Ilešič, Fran, ed. 1908. Trubarjev zbornik. Ljubljana: Matica slovenska.

J. Sl. ... c. 1874. Čestilci Preširnovi! Slovenski Narod (December 16th): 2-3.

Jezernik, Božidar. 2014. Mesto brez spomina. Javni spomeniki v Ljubljani. Ljubljana: Modrijan.

Jurčič, Josip. 1876. Samo Nemci ne! Slovenski Narod (July 20th): 1.

Kleinmayr, Julij plem. 1881. Zgodovina slovenskega slovstva. Klagenfurt: Družba sv. Mohorja. 
Lampe, Frančišek. 1894. Slovenija in svetla habsburška hiša. Dom in Svet 17: 513-514.

Lončar, Dragotin. 1909. Dr. Janez Bleiweis in njegova doba. In: Josip Tominšek (ed.), Bleiweisov zbornik, pp. 141-244. Ljubljana: Matica Slovenska.

Luznik, Valentin. 1862. Iz Tomina. Novice gospodarske, obrtniške in narodne (March 5th): 77.

Mahnič, Anton. 1889. Slovenski katoliški shod. Rimski Katolik 1: 563-578.

Markovits, Andrei S. 1982. Empire and Province. In: Andrei S. Markovits, \& Frank E. Sysyn (eds.), Nationbuilding and the Politics of Nationalism, pp. 1-22. Cambridge, MA: Harvard Ukrainian Research Institute.

-nc. 1889. Zopet narodna slavnost. Slovenski Narod (July 16th): 1.

Okey, Robin. 2001. The Habsburg Monarchy c. 1765-1918. From Enlightenment to Eclipse. Basingstoke: Macmillan.

Opazovavec. 1905. Valjhun ravna po svoji slepi glavi .... Slovenec (September 16th): 1-2.

Prepeluh, Albin. 1938. Pripombe knaši prevratni dobi. Ljubljana: Založba Univerzitetne tiskarne J. Blasnika nasl.

Rigney, Ann, \& Joep Leerssen. 2014. Introduction. Fanning Out from Shakespeare. In: Joep Leerssen \& Ann Rigney (eds.), Commemorating Writers in Nineteenth-Century Europe. Nation-Building and Centenary Fever, pp. 1-23. Basingstoke: Palgrave Macmillan.

Sernec, Josip. 1927. Spomini. Ljubljana: Komisijska založba Tiskovne zadruge.

Sperber, Jonathan. 2001. Churches, the Faithful, and the Politics of Religion in the Revolution of 1848. In: Dietr Dowe et al. (eds.), Europe in 1848. Revolution and Reform, pp.708-728. New York: Berghahn.

Stritar, Josip. 1866. Preširnove poezije. In: Jožef Jurčič \& JožefStritar (eds.), Pesmi Franceta Preširna, spésnikovo podobo, znjegovim životopisom in estetično-kritičnim uvodom, pp. 13-48. Ljubljana: Oton Wagner.

Tavčar, Ivan. 1891. 4000: času primerna povest iz prihodnjih dob. Ljubljanski Zvon 131-139, 195-202, 259-266, 323-330, 387-393, 451-460, 515-524, 579-588, 645-654, 707-718.

Toman, Lovro. 1858. O Vodnikovem godu. Novice gospodarske, obertniške in narodne (January 27th): 29-30.

Toman, Lovro. 1862. Rojakom! Novice gospodarske, obrtniške in narodne (January 8th): 9-10.

Vošnjak, Bogumil. 1913. Študije k problemu jugoslovanske narodne misli. Veda 524-572.

Young, James E. 1993. The Texture of Memory. Holocaust Memorials and Meaning. New Haven, CT: Yale University Press. 


\section{VLOGA VELMOŽ, NOSILCEV SLOVENSKEGA NACIONALIZMA}

Vzpon slovenskega nacionalizma $v$ drugi polovici 19. stoletja je pred nacionalisticne elite večnarodnega (vielvölkisch) Avstrijskega cesarstva postavljal specifične omejitve tako glede razpoložljivih instrumentov kot njihove rabe. Slovenski nacionalisti so morali posebej skrbno paziti, da pri osrednjih oblasteh ne bi zbudili pomislekov, da gre pri njihovem delovanju za politična gibanja, kaj šele za politično opozicijo. Zato so narod predstavljali kot cesarju neuklonljivo vdano in zvesto skupnost. Tako je bilo vse do leta 1918 slovenstvo sprejemljivo le ob pogoju, da ni bilo izključevalno vodnosu do Avstrijskega cesarstva.

Evropski nacionalizmi tistega časa so svoje ideje propagirali s poudarjanjem velikih političnih enot v bolj ali manj oddaljeni preteklosti, sodelovanje pripadnikov določenega naroda $v$ bojih "za velike ideale " $v$ preteklosti in dejanja velikih mož, predstavnikov narodove kulture. Za slovenske nacionaliste je bila izmed navedenih primerna le tretja možnost - poudarjanje velikih mož, med njimi zlasti tistih, ki so govorili v slovenskem jeziku. Zato so oblikovali podobo slovenskega naroda kot ločenega od države, za njegov obstoj je bila pomembna samo kultura, zlasti ohranitev slovenskega jezika.

$V$ preteklosti so delovale neštete pomembne osebe, vendar so nacionalisti izmed njih izbirali tiste, ki so dajali legitimnost njihovemu prizadevanju in so jih lahko predstavili kot poosebitev svojih vrednot. V tem smislu je narodna prebuja nujno pomenila politizacijo kulture in mobilizacijo kulturnih oblik za ideološke cilje. Posamezni pripadniki naroda, ki jih je skupnost sprejela za velmože, so bili spremenjeni $v$ podobo naroda. Iz njihovega kulta so se pripadniki naroda učili solidarnosti in ob primerjavi s pripadniki drugih narodov gradili občutek lastne vrednosti; s tem so prispevali h kulturni homogenizaciji pripadnikov naroda in $k$ zarisovanju ločnic med Nami in Drugimi.

Predstavljanje preteklosti je vedno tesno povezano s političnimi procesi, predvsem s politiko reprezentiranja, tj. s sprejemanjem odločitev o tem, kdo labko predstavlja koga, kako, kje in $s$ čim; kdo nadzoruje zgodovino, kdo ima moralno pravico, da jo nadzoruje, in v čigavem interesu to počne. S slavljenjem določenih zgodovinskih osebnosti niso zgolj prikazovali določene zgodovine, temveč so jo tudi soustvarjali za javnost. Tako oblikovana zgodovinska zavest je dajala tistim, ki so jo predstavljali, pečat legitimnosti, ker so v njej videli »objektivno resnico", ločeno od oblasti in politike. Ker je bil tako oblikovan spomin naroda namenjen potrebam narodnega boja, je bila preteklost, ki so jo predstavljali velmožje, v celoti produkt sedanjosti, njenih ideoloških in političnih nasprotij, pogajanj in bojev. Zato se je kolektivni spomin stalno spreminjal, popravljal, dopolnjeval in prilagajal spremenjenim razmeram, dokler ni po velikem prevratu po koncu 1. svetovne vojne podoba narodne preteklosti dobila povsem antagonističnega videza v odnosu do zgodovine Avstrijskega cesarstva in njegovih rekonstrukcij preteklosti.

Veliki možje v slovenski preteklosti torej niso nastajali kar sami po sebi, temveč so jih za take razglasili drugi. Vvsakem narodu obstaja več skupin, ki tekmujejo za družbeno prevlado; zato je v njem tudi več kolektivnih spominov na zgodovinske osebnosti in dogodke. Ti tekmiški spomini niso nekaj statičnega, temveč gre za proces nenehnega spreminjanja "smiselnega" in 
"nesmiselnega" gradiva. Ohranjanje narativnih podob o osebah in dogodkih iz preteklosti je torej proces nenehnega (pre)vrednotenja njihovega pomena, zgodbe same pa izražajo ideološke, politične, etične in druge koncepcije, skaterimi posamezniki interpretirajo in vrednotijo, kaj je še aktualno in kaj je že stvar preteklosti, kaj je pomembno in kaj ni več.

Prof. Božidar Jezernik, Department of Ethnology and Cultural Anthropology, Faculty of Arts, University of Ljubljana, Zavetiška 5, SI-1000 Ljubljana, bozidar.jezernik@ff.uni-lj.si 